\title{
Researching ELT 4.0 and Transmediality: Fostering Transliterate Reading through Transmedia Storytelling
}

\author{
R. Della N Kartika Sari Amirulloh and Muhammad Amir Zikri \\ Universitas Pendidikan Indonesia (UPI), Bandung, Indonesia
}

\section{Abstract}

The notion of Education 4.0 has directed to the utilization of various media platforms in teaching, which, in this context, is the adoption of Transmedia storytelling. Transmedia storytelling is the material presented to the students during the teaching and learning session that aims at fostering students transliterate reading. Through transmedia storytelling students are introduced to reading activities that enable them to read through multiple media platforms presented in class. A number of studies have been done in researching transmediality in the area of communication studies, however only little is known in ELT research. Therefore, this paper endeavors to explore the ways

Corresponding Author:

R. Della N Kartika Sari Amirulloh della@upi.edu

Received: 1 July 2019

Accepted: 18 July 2019

Published: 31 July 2019

Publishing services provided by Knowledge E

(c) R. Della N Kartika Sari Amirulloh and Muhammad Amir Zikri. This article is distributed under the terms of the Creative Commons Attribution License, which permits unrestricted use and redistribution provided that the original author and source are credited.

Selection and Peer-review under the responsibility of the AICLL 2019 Conference Committee.

\section{G OPEN ACCESS} in which transmedia storytelling helps foster students' transliterate reading. Adopting Transmedia Play and Storytelling theories grounded in transmediality, the paper utilizes a case study as the research design. Employing classroom observation and students' response sheets, the findings reveal that transmedia storytelling promotes students transliterate reading through facilitating them in engaging with multiple types of visual, audio and interactive media activities. It helps them develop awareness in three areas: 1) awareness of the function of pictures for story comprehension and vocabulary acquisition; 2) awareness of the way sound helps for narrative elements interpretation; 3) awareness of the needs of text-reader transaction through new media for comprehension.

Keywords: Transmedia Storytelling, Transliterate Reading, media platforms

\section{Introduction}

In the context of Industrial Revolution 4.0, the teaching-learning process has become a challenge in schools and universities because of the fact that technology that had been developed today made traditional teaching methods such as lectures, recitations and memorization techniques less effective and less interesting for the students (Munaro \& Viera, 2016). This issue led the educators to face difficulties in trying to implement classical teaching methods in the classroom as students do not find it interesting. Therefore, the break of traditional ways of teaching, combined with the rapid development 
of technologies, especially in terms of mobile, is a huge changing landscape for the educators. This new era is an eye opener for the educators to develop a new design of learning experiences for the students (Rodrigues \& Bidarra, 2014). Since then, educators have come out with various type of learning experiences that consist of technologies in order to facilitate students' learning experiences. Technologies such as electronic whiteboards, desktops, projectors, mobile learning, computer networking and the use of Artificial Intelligence, have been introduced in the class in order to attract the students' attention so that the teaching and learning process can be effective.

The cause of developing a new design of learning experience can be strengthened by the fact that teenagers today who allegedly being called as the Generation Z, are different compared to the generations before since they are more critical, dynamic, demanding, self-taught. As stated by Adam \& Hams (1996), lecturing process where students merely sit in the classroom and listen passively to what is being taught by teacher is not suitable anymore with recent regression towards digital classroom. They want to be tested and have the opportunity to make their own decisions.

This fast-paced interactive culture has changed the way how teaching was supposed to be. Some of the platforms used by the students are the social media platforms and also content creation tools. The key to this issue is trans literacy, that is, an ability to read, write and interact over a variety of platforms and media (Thomas et. al., 2007) that the students need to possess in order to survive in the $21^{\text {st }}$ century. If educators can combine the ability of trans literacy, the development of multimedia in different channels and the use of internet, a new dimension can be introduced, which is the integration between digital worlds with the physical one (Pitts, Ireton \& Wards, 2014).

In the context of this vibrant, irreducible, fast-paced growing world, the term "Transmedia Storytelling" can be said to be shone its light among people who create, use media and technology to make a better English teaching-learning experience. Transmedia, which carries the meaning of "across media" can be described as a combination of multiple channels for the purpose of constituting a unified and coordinated entertainment experience. This can be supported by the description explained by Jenkins (2006) where he derived Transmedia as a "synergy" that is being integrated together by modern media companies. Transmedia storytelling creates space for students to develop a personal connection with complex media as it involves representation, meaning, embedded in imagery, sound, and narrative. TS has been implemented in the classroom to develop students' trans literacy skills which include the ability to read, write and interact over variety of platforms and media (Thomas et. al. 
2007). Therefore, this present research is aimed at exploring how a technology-assisted language learning such as TS foster students' trans literacy skills.

\section{Literature Review}

Transmedia originally comes from the collaboration of two words: "Trans" and "Media". According to Avery (2000) and Gambarato \& Alzamora, 2012 (2013), "trans" in this case holds the meaning of "beyond", "traverse", "through" and the dissemination of the ideas of wholeness. Jenkins (2006) further simplifies "transmedia" as "across media" or "through communication platforms". However, according to Baarspul (2012), the origin of the concept of transmedia actually goes back to the year of 1991, by the work of Marsha Kinder, who published a book entitled Playing with Power in Movies Television and Video Games in 1991. Kinder (1991) devises transmedia as a set of narrative and non-narrative media elements that are spread systematically across various platforms. Narrative elements that are meant by Kinder (1991) include things such as plot, setting, and characters. Meanwhile, non-narrative elements cover items such as mode of participation (e.g., ways to play a part in contribute in a story or types of actions in a video game) or design features (such as instructional design in an in-person activity).

Kinder (1991), contends that transmedia allows the recipient to "recognize, distinguish and combine different popular genres and their respective iconography that cut across movies, television, comic books, commercials, video games and toys". Kinder (1991) also argues that transmedia (or "transmedia intertextuality" in Kinder's terms) provokes some response from the viewers, which makes them "being sutured into imaginary identification with a fictional character and fictional space."

Further, Herr-Stephenson and Alper (2013) claim that transmedia depends on children's abilities to decode, remix, create and circulate many kinds of media content, from Sesame Street to Star Wars, through contexts which includes schools, extended learning programs and home environments. From the derivation, they come out with "Transmedia Play" which can be described as the approach regarding children's experimentation with, expression through and participation in a transmedia experience that acknowledges cultural engagement, respects their thoughts and feelings and builds up and upon $21^{\text {st }}$ century literacies. It is significant to know that the term "Transmedia Play" does not carry the meaning "play" or "drama" in the literature scene but, it theorizes on how children read and interact with contemporary media across platforms.

As cited by Rodrigues and Bidarra (2014), Herr-Stephenson and Alper (2013) noted that "Transmedia Play" favors learning in different ways: 
1. Promotes new approaches to reading, as children must learn to read both written and multimedia texts (across multiple media).

2. Encourages joint media engagement, providing opportunities for families to experience transmedia together.

3. Can support constructivist learning goals - it involves exploration, experimentation and remix, which focuses the active role of the learner in constructing knowledge by performing to make connections among information in a specific context.

This theorization of students' engagement with multiple media platforms can be implemented through Transmedia Storytelling (Jenkins, 2006, 2008, 2010; Scolari, 2009, 2014), which is defined as a specific narrative structure that broadens through both different languages (verbal, iconic, etc.) and media (cinema, comics, television, video games, etc.). Combined contents are delivered in accordance with different media, platforms and different languages. In this case, consumers experience different parts of the story through different channels and they are surrounded and wrapped up with the story in all kind of aspects. Phillips (2012) articulates the same idea that Transmedia storytelling can also be described as a technique that transfers messages, ideas, or story series to mass audience by using multimedia platforms in a planned and rational fashion. Clearly, transmedia storytelling means exposing the interesting parts of a story by using a various communication platform and delivering the whole of the story into use through contrasting dimension and experiences.

Having seen the significant pedagogical potential of Transmedia Play and Transmedia Storytelling, Herr-Stephenson and Alper (2013) believes that this theoretical construct is of importance to foster students' trans literacy, support social skills and cultural competencies.

Trans literacy is a new concept that emerged from multiple scholars and educators. It is derived during various types of things that are being presented in an increasingly complex information and communication environments, advance further from all perspectives. Thomas et. al. (2007) derives trans literacy as a person's capability to read, write and interact with materials through a range of platforms, tool and media from signing and orality through handwriting, print, TV, radio and film, to digital social networks. In $21^{\text {st }}$ century, the perspective of what it means to be literate has changed. Thomas's definition offers a unifying perspective of what it means to be literate in the $21^{\text {st }}$ century. Linguistically, Sukovic (2014) discusses that the word is needed to not only master multiple literacies, but also to create the ability to adapt and be flexible 
that are necessary for learning and work in a rapid-growing environment. The accurate configuration of skills, modes and technologies depends on the context.

Trans literacy is originated from Alan Liu's Trans literacies Project where it was first developed at the University of California in 2005. It was later being developed further by Thomas et. al. (2007) in Production and Research in Trans literacy (PART) group at De Montfort University. Thomas et. al. (2007) exposes trans literacy as a concept that has the ability to capture dynamic relationships between different types of literacies, technologies and social cultural contexts. Stornaiuolo, Smith and Philips (2017) extend the original definition of Liu's plural conception of trans literacies from the work of scholars in the New Literacy Studies and multiliteracies that examines the situated, contingent and ideologically rooted nature of meaning making across modes. They argue that, by deliberately attending to how people make meaning across interactions among people, things, texts, contexts, modes and media, a trans literacy approach can foreground how people and things are mobilized and paralyzed, facilitated and restricted, in different measure in relation to institutions and systems with long histories.

In the context of literacy at schools, one of the forms of trans literacy is transliterate reading. As stated by Thomas et. al. (2007), it is the ability to read, write and interact across multiple platforms and media. In details, he describes transliterate reading as abilities to read through a different range of media, be it in the form of handwriting, conventional printed words, spoken words, any types of electronic platform, from documents on a computer through to the online material, social networking and also texts from a mobile phone.

One of the ways to foster is through the practices of Transmedia Storytelling as the story world creates an atmosphere for learning where students are given the opportunity to explore different angles of the narrative through webisodes, location-based quest and a motion book sequence (Rodrigues \& Bidara, 2018). Hence, the more invested the students are into the story world, the closer they will feel connected to the content. The way stories are presented and interactions with story characters through multiple platforms as well as with peers inside the community of the story world can help the student to participate in the story world while also developing their transliterate reading skills.

Transmedia storytelling enrichments that vary through multiple forms of media such as animation, pictures, sound and visuals can foster students transliterate reading skill. By taking advantage of these features, Transmedia storytelling can act as the facilitator for students transliterate reading skill and also in language acquisition. 


\section{Research Method}

Employing a case study, this research was conducted in one of the public junior high school in Bandung, West Java.

The participants involved in this study were an eighth-grade class of junior high school consisting of 24 students. This study used purposive sampling technique to select one class to become sample of the research based on the consideration of the school authority. The purpose of using this technique is to ensure the researcher would get more effective data from the participants. The reason this class has been chosen to be the participants are because they are considered as "bilingual" students by the class' English teacher.

The instruments used in this study were classroom observation and student's response sheets. Classroom observation is the process of gathering open-ended, firsthand information by observing students and classroom during the teaching-learning experience (Creswell, 2012). While according to Alwasilah (2009), classroom observation is a systematic and planned observation to gather information in which its validity and reliability are controlled. Based on the two statements above, observation is a way to find some information which is crucial for the study.

There were two observers in this study; a teacher-researcher as a participant observer and a colleague as an external observer to increase the validity of the instrument. During the observation, the participant observer also engaged with the activities such as asking questions to the students, clarifying problems that occurred in the learning process. Other than that, the participant observer also interviewed the students during the activity. In order to get a more accurate detail regarding the observation, the researcher also videotaped the teaching-learning session. As it is stated by Gall and Borg (2003), an observation that was conducted through videotaping can obtain more accurate data. In addition, through videotaping, the observation can be replayed several times in order to check and fix the corresponding data (Frankel \& Waellen, 2009).

Student's response sheet was also utilized for students to write their opinions and views regarding a set of themes related to the story. Creswell (2008) adds that students' responses are appropriate to get deeper information in qualitative research.

\section{Result and Discussion}

This study was conducted to find out the potential of Transmedia Storytelling in fostering Transliterate Reading. The findings reveal that transmedia storytelling promotes 
students transliterate reading through facilitating them in engaging with multiple types of visual, audio and interactive media activities. It helps them develop awareness in three areas: 1) awareness of the function of pictures for story comprehension and vocabulary acquisition; 2) awareness of the way sound helps for narrative elements interpretation; 3) awareness of the needs of text-reader transaction through new media for comprehension.

\subsection{Awareness of the function of pictures for understanding con- tent and vocabulary acquisition}

Pictures are significant in transmedia storytelling as they help students understand the content of storyline. This can be seen from the classroom observation that had been conducted where students explored through the use of the pictures to make meaning. The examples of how the pictures support the students in comprehending the story can be seen as follows:

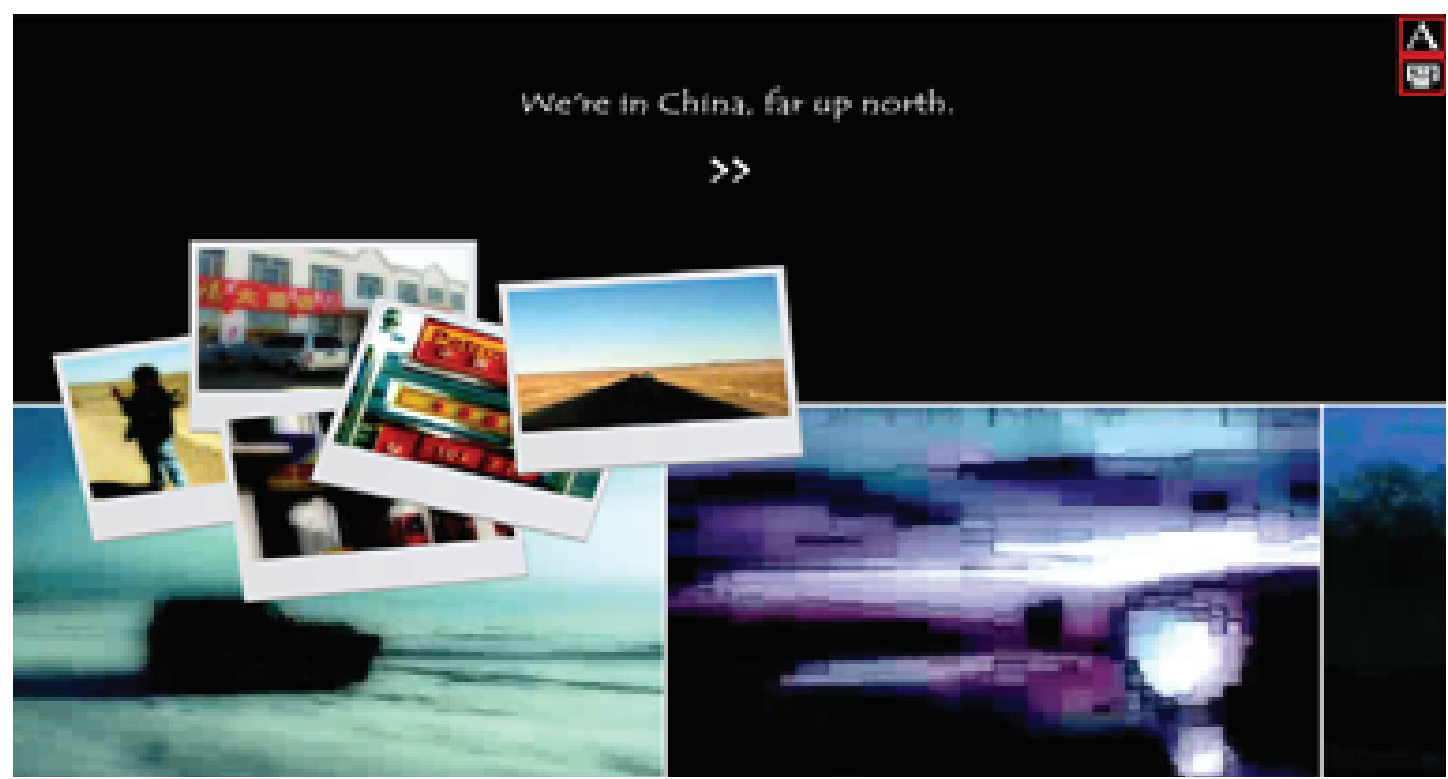

Figure 1

The scene in the story showed polaroid pictures of places that Alice and her family live in. There were five pictures in total, with all of them consist of different places. The first shown picture was a picture of a lady posing on the side of the road in the dessert. The next three pictures were pictures of shop lots with signboards that were in Mandarin. While in the last picture, it was a picture of a road in the dessert.

From the observation, it can be seen that the students were focused heavily onto the pictures as it appeared that they were suggesting and giving opinions towards 
one and another. This situation fulfilled the statement by Scrivener (2005) who claimed that visual stimuli are likely to engage students' attention and they might be more responsive. The researcher concluded that they were trying to interpret the photos, in order to understand what was going on in the story. To ensure the students had the complete idea of what was going on in this scene, the teacher asked the students.

Teacher: Okay class, what can you see in this scene?

Students: Polaroid pictures!

Teacher: Can someone explain to me what is in the polaroid pictures?

Student 1: A woman!

Students 2: Shops sir!

Students 3: Jalan raya! (Road)

\section{Excerpt 1}

In the excerpt 1 above, we can see that the students had full knowledge of what were in the polaroid pictures. Wright (1989) claimed that visual images can inspire students and making them giving full attention and want to take part of the teaching and learning session. This was particularly true since the students were very responsive when they were asked questions regarding the polaroid picture.

In transmedia storytelling, pictures also helped the students with their language or vocabulary acquisition. Picture can be considered as a great tool as it allows us to focus on meaning rather than on form. In Inanimate Alice, there were a lot of pictures that were discovered by the students. Through the observation, it can be seen that these pictures were discussed between the teacher and the students. These pictures discussions helped the students in improving their English language and also helped them in acquiring new form of words and vocabulary during the teaching and learning session. Elley (1991) argued that children can acquire new language and vocabulary from the context of a picture as opposed to a carefully planned and structurally sequenced grammar or vocabulary textbook. Through interaction with meaningful and interesting stories, children will learn story elements, sentence structure and new vocabulary (Elster, 1998).

One of interesting moments of vocabulary acquisition can be seen during the scene where Alice was explaining about what Alice and her mother like to do in their free time.

In Figure 2, the screen was divided to two sections where the first section displayed an animation of a white canvas being painted continuously. On the second section of 


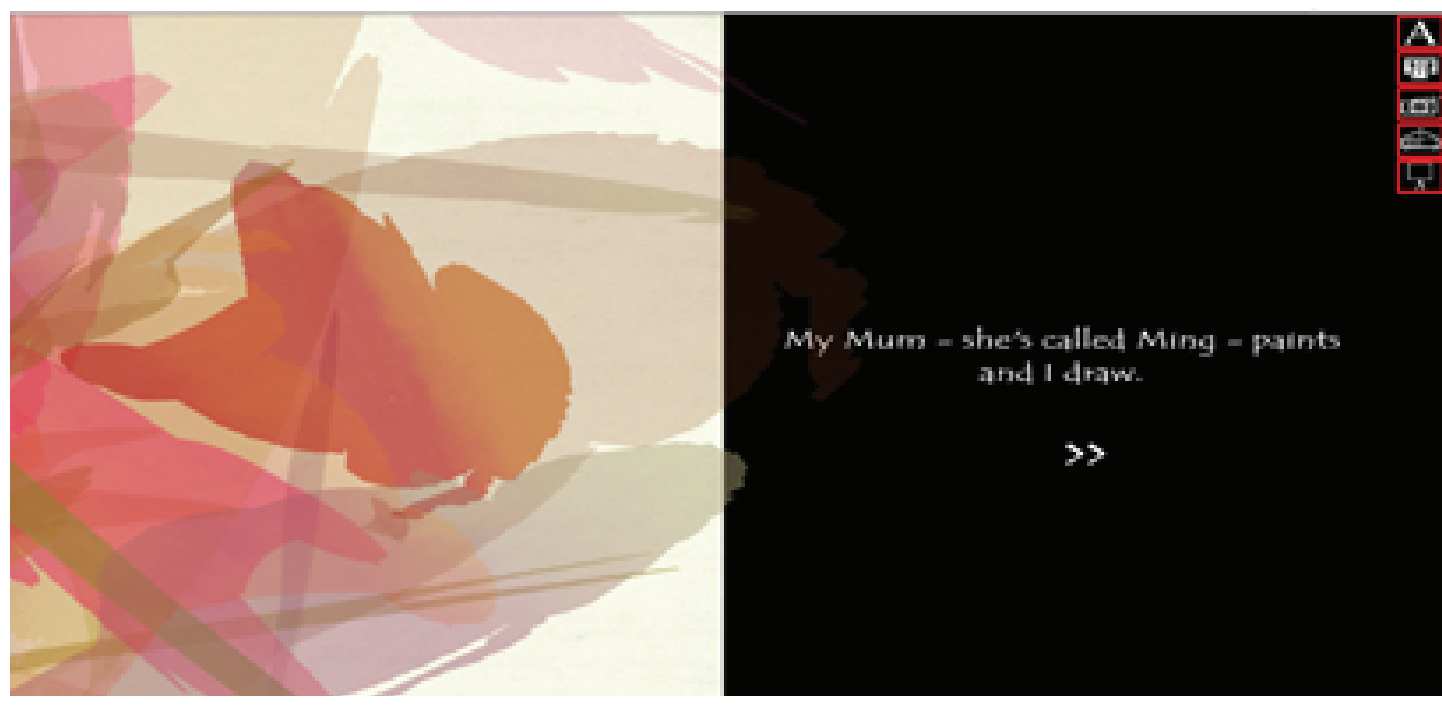

Figure 2

the screen, contained the sentence where Alice explained. Alice stated that her mother, Ming "paints" while she "draws". The students were excited looking at the animation of the white canvas. Amused by the reaction of the students, the researcher asked the students about the animation. the students were confused between a painting and a drawing. When being asked about the differences between the verb "paint" and "draw", Student 18 highlighted that both of the verbs carry the same meaning in Bahasa Indonesia. The teacher was quick to enlighten the students the differences by asking the students the tool used in both actions. However, the students were having difficulty in answering the right tool for painting. The teacher gave them a clue based on the moving picture and Student 12 was quick to answer the question. It showed that the animation helped in engaging Student 12 to find the correct answer. As it was stated by Allen (1983), it is effective using pictures to convey the meaning as it helps the students to remember the lexis better. The animation managed to make the students understood the differences between painting and drawing, as it was clear that they realized that it was Ming who was painting on the canvas in the animation.

\subsection{Awareness of the way sound helps for narrative elements interpretation}

Singh (2005) defined audio-visual as any devices which by sight and sound increase the individual's experience beyond than what is acquired through reading. The researcher discovered that Transmedia Storytelling also support students' EFL learning through sound/audio-visual. In the story Inanimate Alice, sound played a significant role. It was being used for multiple of purposes such as telling the audience what was happening 
as well as setting up the mood of the story. These purposes helped the students in their EFL learning as follows:

\subsubsection{Interpreting the setting}

The sounds in Inanimate Alice invoke many discoveries for the students. Middleton (2009) highlighted that audio has a demonstrated capacity to facilitate authentic engagement, allowing students to connect in various ways to the outside world as listeners. While using transmedia storytelling in the teaching and learning session, there were moments were audio-visual showed its ability in supporting the students. It can be seen that audio-visual helped the students to try comprehending the plot of the story.

The significance of sound in supporting the students interpreting the story can be seen from the beginning of the story where Alice was introducing herself to the readers. The image that was being shown by the projector during the scene was black in colour and there were only sentences and sound accompanying the storyline.

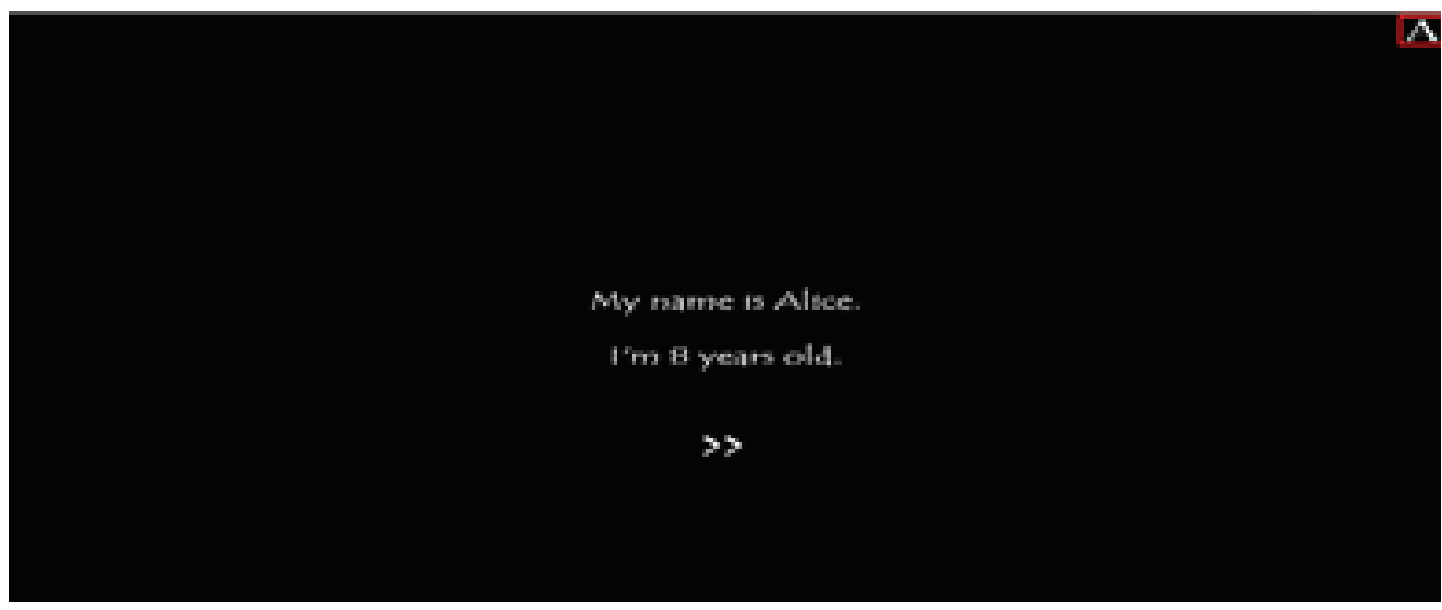

Figure 3

The sound that was played in this scene can be said to be the sound that came from a fax machine. Students can see how the sound played a crucial role in trying to explain the story to the readers at the beginning of the story. Student 1 raised his hand and asked the teacher what sound is that, the teacher then asked to guess what it is. To promote critical thinking, the teacher opened a discussion with the students about what was the message behind the sound. The teacher started the discussion by asking the students what is the function of a fax machine. There were various answers from the students. There were also notable answers that caught the teacher's attention. All of the answers above were technically correct as fax machine is used to send documents 
by scanning and transmitted the scanned data to another telecommunications link. The teacher followed through a question by asking the students what is the writer is trying to tell us? It was quickly answered by Student 5 . She answered, "To tell us that Alice is 8 years old!". It is interesting to see how the students interpret the meaning of the storyline by just listening to the sound and their own experience. It showed that transmedia storytelling is playing its part in helping the students in understand the story better.

\subsubsection{Interpreting the Mood/Atmosphere}

In Inanimate Alice, the audio visual aid also helped the students in experiecing the emotion of the story. The sounds that were played throughout certain scenes can be seen developed emotions amongst the students. The researcher discovered that the sounds made them feel various kind of emotions. Some of the emotions were written by the students in the student's response sheets. The emotions that they wrote in the students' response sheets were the feeling of "scared/creepy", "weird", "relaxing" and "happy". These emotions, which were affected by the music and sound from the story is called as "Emotional Contagion" according to Juslin \&Vastfjall (2008). It is a process where an emotion influenced by a piece of music because the listener interprets the emotional expression of the music and then "copies" this expression internally, where the emotional representations in the brain consist of either a more a direct activation from the brain or a peripheral feedback from muscles. For an example, music or sound that might have a sad expression (e.g.: slow tempo, low pitch, low sound level) influences the feeling of sadness in the listener (Juslin \& Sloboda, 2001).

These kind of emotions were developed throughout the storyline. One of the apparent emotions that can be seen from the observation is the feeling of "weird". The student who explained he felt the sound was weird in the student's response sheet was approached by the researcher. When being asked about the feeling of "weird", the respondent, which was Student 19 answered that he felt weird when he heard the audio where there was a traditional music and a girl singing in Mandarin language played in the background. It was the same sound that the researcher mentioned in the section before where the students developed the understanding that Alice were looking for her father. Student 19 told the researcher that he felt weird because he cannot really fathom what the sound was like, which was similar to those of student 1 and student 4. This is evident that there were more than one student who felt that way. The researcher believed that it was probably the author's motive to make the readers feel that way 
in order to promote effective discussions amongst the readers. The sound did sound interesting, however, it required a long period of time to be discussed with the students.

\subsection{Awareness of the needs of text-reader transaction through new media for comprehension}

There were also scenes where the readers needed to interact with the story in order to make the story developed. Students mostly interacted with $b a-x i$, which is the gadget that Alice owns. Ba-xi is a multi-purpose gadget that may do variety of things such as chatting, sending messages, draw, take pictures and etc. Their interactions with $b a-x i$ mostly helped them in interpreting the story. An example can be seen from the scene where Figure $\mathbf{4 . 1 3}$ was being shown on the screen.

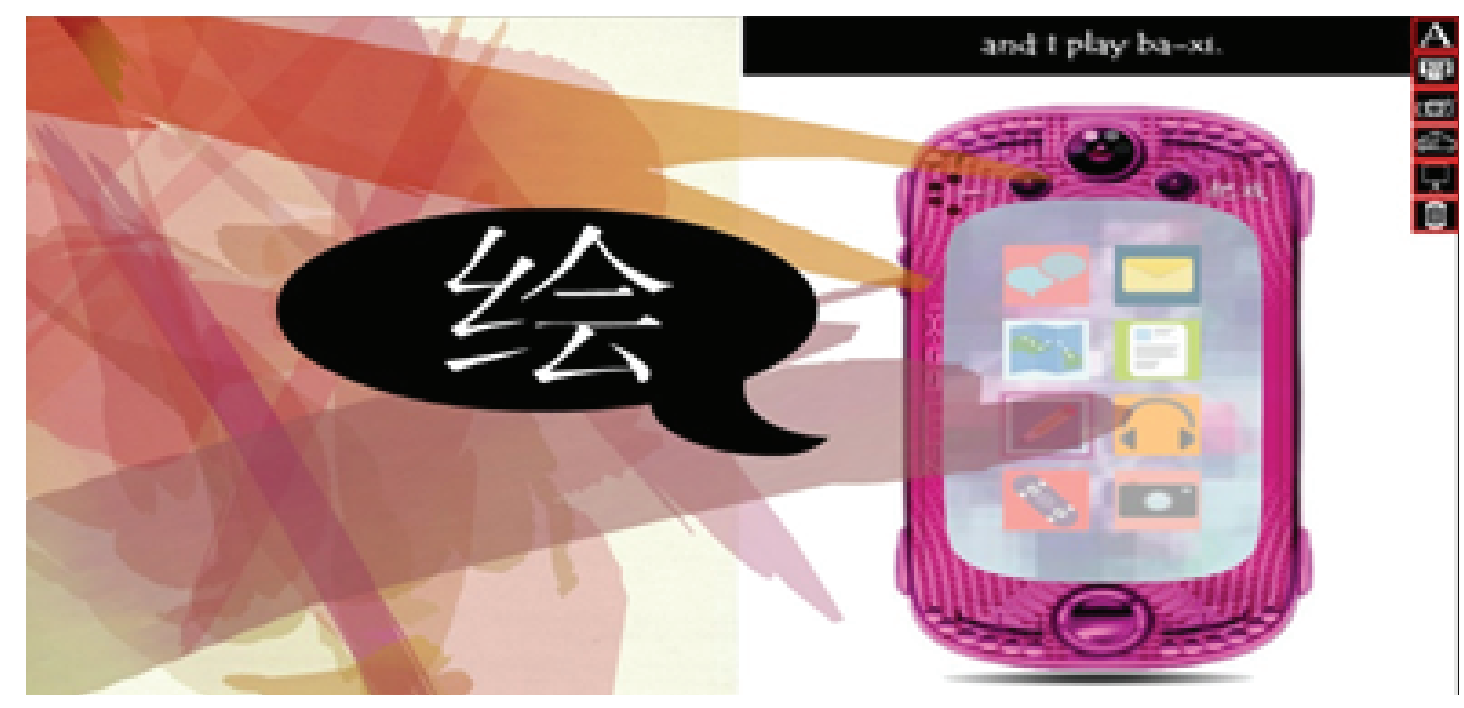

Figure 4

Alice explained about what she and her mother did when they were at the base camp. Alice mentioned that she played with her ba-xi. During this scene, the ba-xi was turned on automatically but the story was unmoved after the ba-xi was turned on. The scene required the reader to click on the correct application that was in the ba-xi. The teacher called on one volunteer to try interacting with the scene. From the interaction, the students could determine what Alice meant by "play" as they needed to click the correct application in order for the story to proceed. The application that the volunteer needed to click was the application with the "pencil" as the symbol of the application. From here, the students could interpret what Alice meant by "play" was actually her, using the drawing application to draw. 
Another example of interactive activity that included use of ba-xi in Inanimate Alice was the scene where Alice was trying to take pictures of flowers on the side of the road.

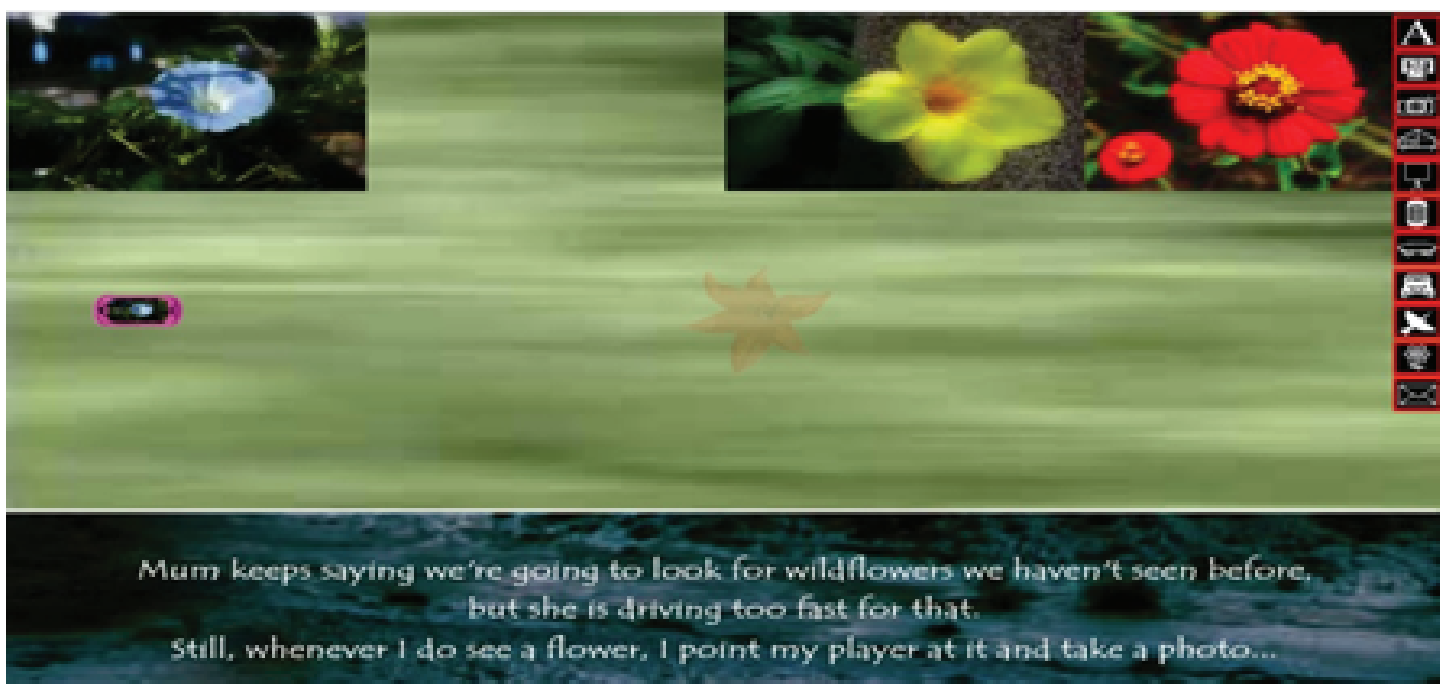

Figure 5

In this scene, the readers will be seeing Alice's point of view in the story. Whenever Alice sees a flower, she points her ba-xi at the flower and takes a photo. From being in Alice's point of view, the readers can experience what Alice was experiencing while taking the pictures of the flowers. The students, in this case, developed the feeling of amusement as some of them stated that they never experienced this kind of learning before.

The volunteers were very excited in trying to take photos of the flowers. It can be seen from this interactive activity that the students were really excited because the scene was something that they can relate to. These students, which are the Generation $Z$, are familiar with electronic gadgets. They use electronic gadgets almost every hour in their daily lives. To see something that can be related with their daily lives' activities or experiences heightened their enthusiasm in reading the story. Students' admiration towards ba-xi cannot be denied. This can be seen from the result of the student's response sheets which the students have answered. There were 17 out of 24 students who answered that they liked the part where the $b a-x i$ was being used in the story. It was because they found ba-xi as an interesting gadget to be interacted with while reading the story. The students also mentioned that they find it interesting because of its multifunctional purposes where it can be used as a drawing tool, navigating maps and also capturing photos.

Clearly, today's students have been exposed to trans modality (Shipka, 2016); the way students engage with different modes, genres, communicative technologies that 
will greatly affect the way the make sense of a text and negotiate meaning. Moreover, through engaging with new media such as in this type of Transmedia Storytelling, students will gradually develop agency and creativity as they are provided with choices to finish the story. The idea of the inclusion of transmedia or trans modality texts is considered as a challenging, interesting and comprehensible in the part of the students, which will not only foster their transliterate reading ability but also gradually develop their critical thinking skills (Sinambela \& Saragih, 2018).

\section{Conclusion}

This paper investigates the utilization of Transmedia Storytelling to meet the demand of English Language Teaching in the era of 4.0, specifically in fostering students' transliterate reading. Given interactive online story 'Inanimate Alice', clearly that Transmedia Storytelling facilitates students to develop awareness of trans modality elements such as awareness of pictures, sound and interacting through new media, which are of importance in the development of transliterate reading skills.

\section{References}

[1] Allen, V. F. (1983). Techniques in teaching vocabulary. New York, N.Y.: Oxford University Press.

[2] Alper, M. \& Herr-Stephenson, R. (2013), 'Transmedia play: Literacy across media', Journal of Media Literacy Education, 5:2, 366-69.

[3] Alwasilah. (2006). Perspektif Pendidikan Bahasa Inggris di Indonesia. Bandung: CV. Andira.

[4] Avery, R. et al. (Ed.) (2000). English-Turkish Redhouse Dictionary. Istanbul: Sev Printing and Publishing.

[5] Baarspul, M.P. (2012). Where transmedia storytelling goes wrong: A preliminary exploration of the issues with transmedia storytelling, Unpublished Master's Thesis TFT. Retrieved from Utrecht University Repository.

[6] Creswell, J.W. (2008) Educational research: Planning, conducting, and evaluating quantitative and qualitative research. Upper Saddle River, NJ: Pearson/Merrill Education.

[7] Creswell, J. W. (2012). Educational research: Planning, conducting, and evaluating quantitative and qualitative research (4th ed.). Upper Saddle River, NJ: Pearson. 
[8] Elley, W. (1991). Acquiring literacy in a second language: The effect of book based programs. Language Learning 41, 375-411.

[9] Elster, C. A. (1998). Influences of text and pictures on shared and emergent readings. Research in the teaching of English, 32(1), 43-78.

[10] Fraenkel, J.R. \& Wallen, N.E. (2009). How to Design and Evaluate Research in Education ( $7^{\text {th }}$ ed). New York. McGraw-hill.

[11] Gall, M. D., Gall, J. P., \& Borg, W. R. (2003). Educational research: An introduction $\left(7^{\text {th }}\right.$ ed.). Boston: Allyn \& Bacon.

[12] Gambarato, R., \& Alzamora, G. C. (2012). Transmedia Storytelling Initiatives in Brazilian Media. Medien Journal, 4, 51-60. Retrieved from https://talkingobjects.files. wordpress.com/2012/01/Gambarato\&Alzamora,2012_mj2012_4_bric.pdf

[13] Jenkins, H. (2006). Convergence Culture: Where Old and New Media Collide. NY: NYU Press.

[14] Jenkins, H. (2008). "Searching for the Origami Unicorn: The Matrix and Transmedia Storytelling," Convergence Culture: Where Old and New Media Collide. New York: New York University Press. Pages 93-130.

[15] Jenkins, H. (2010). Transmedia Storytelling and Entertainment. Continuum: Journal of Media \& Cultural Studies, 24(6), 943-958. http://doi.org/Article

[16] Juslin, Patrik \& Västfjäll, Daniel. (2008). Emotional Responses to Music: The Need to Consider Underlying Mechanisms. The Behavioral and brain sciences. 31. 559-75; discussion 575. 10.1017/S0140525X08005293.

[17] Juslin, P. N. \& Sloboda, J. A., eds. (2001) Music and emotion: Theory and research. Oxford University Press

[18] Kinder, M. (1991). Playing with Power In Movies, Television and Video Games. University of California Press, California.

[19] Middleton, A 2009, 'Beyond podcasting: creative approaches to designing education audio', Alt-J, Research in Learning Technology, vol. 17, no. 2.

[20] Munaro, A. C., \& Vieira, A. M. D. P. (2016). Use of Transmedia Storytelling for Teaching Teenagers. Creative Education, 7, 1007-1017.

[21] Phillips, A. (2012). A Creator's Guide to Transmedia Storytelling: How to Captivate and Engage Audiences Across Multiple Platforms. Ney York: McGraw Hill.

[22] Pitts, J., Ireton, D., \& Ward, B. (2014). Beyond the book: teaching transliteracy through transmedia storytelling. LOEX Quarterly 41(3), 4-10. 
[23] Rodrigues, P., \& Bidarra, J. (2014). Transmedia Storytelling and the Creation of a Converging Space of Educational Practices. International Journal of Engineering and Technology (iJET), 9, 42-48.

[24] Rodrigues, P., \& Bidarra, J. (2018). Transmedia Storytelling as a Framework for Effective Blended Learning Design. In The Envisioning Report for Empowering Universities. Eds. G. Urbachs \& L. Konings. Lisbon: EADTU

[25] Scrivener, J. (2005) Learning teaching: a guidebook for English language teachers. 2nd ed. Oxford: MacMillan.

[26] Scolari, C.A (2009) “Transmedia Storytelling: Implicit Consumers, Narrative Worlds and Branding in Contemporary Media Production". International Journal of Communication 3, pp. 586-606

[27] Scolari, C. A. (2014). Transmedia storytelling: New ways of communicating in the digital age. The International Journal of Multimedia \& Its Applications (IJMA, 8(6).

[28] Sinambela, S.E. \& Saragih, A. (2018), "Promoting Hots and Better Literacy for EFL Students through the Cognitively Challenging Reading Material" in The 1st Annual International Conference on Language and Literature, KnE Social Sciences, pages 806-815. DOI 10.18502/kss.v3i4.1987

[29] Shipka, J. (2016). Transmodality In/And Processes of Making: Changing Disposition and Practice. College English, 78(3)

[30] Singh, Y. K. (2005) Instructional Technology in Education, New Delhi: Darya Gani

[31] Stornaiuolo, A., Smith, A., \& Phillips, N. (2017). Developing a transliteracies framework for a connected world. Journal of Literacy Research, 49, 68-91.

[32] Sukovic, S. (2014). iTell: Transliteracy and Digital Storytelling. Australian Academic \& Research Libraries, 45(3), 205-229.

[33] Thomas, S., et. al. (2007, December 3). Transliteracy: Crossing divides. First Monday 12(12). Retrieved from http://firstmonday.org/article/view/2060/1908

[34] Wright, A. (1989) Pictures for language learning. New York: Cambridge University Press. 